\title{
Language Endangerment: Issues of Igbo Proverbs
}

\author{
Maria I. Obadan ${ }^{1}$ \\ ${ }^{1}$ Department of Languages and Linguistics, Delta State University, Abraka, Nigeria \\ Correspondence: Maria I. Obadan, Department of Languages and Linguistics, Delta State University, Abraka, \\ Nigeria. Tel: 234-80-2313-2303 E-mail: mariaiobadan@yahoo.com
}

Received: May 4, 2015

Accepted: June 1, $2015 \quad$ Online Published: June 26, 2015

doi:10.5430/elr.v4n3p1

URL: http://dx.doi.org/10.5430/elr.v4n3p1

\begin{abstract}
In the past two decades or so, much attention has been drawn to the issue of language endangerment, especially African languages. Most of these researches have tried to ascertain the endangerment status of various languages in whole by considering mostly the number of speakers. This paper however takes a different approach on this subject of language endangerment. Rather than looking at the language as a whole, this paper examines the gradual loss of an important aspect of the Igbo language; proverbs. The central claim of this paper is that language endangerment is gradual. It starts with the loss of some vital aspects of the language thereby losing its communicative relevance in certain domain. If this trend continues, and more domains lose their communicative relevance, if unchecked, might lead to an eventual total loss of the language. By observing the language use of two different age groups (Elder and Youth groups), this paper was able to highlight a generational gap in the use and interpretation of proverbs by the younger generation. The particular Igbo community that this study is based on is the Ogwashi-uku community in Delta state. Data were gathered from communal meetings of two separate groups; made up of the youths and the elders. Using the linguistic vitality and endangerment (LVE) framework, this paper examines the competence level in the use of proverbs between the older generation of Igbo speakers and the younger generation. Findings show that most youth speakers lack competence in the use and interpretation of proverbs.
\end{abstract}

Keywords: Language Endangerment, Igbo Proverbs, LVE framework

\section{Background to the study}

The loss of a people's culture and language is far more disastrous than it might seem on the surface. Language is more than just an aspect of culture; it is an agent in which culture gains its social context and significance. It does not merely represent a culture but is a contributor to that culture. From vocabulary, to poetry, oral traditions, greetings and humour, these are substances of that culture and not just vessels of communication. The loss of a people's language is a loss of the thorough understanding of their value systems, beliefs, organization methods, and a debilitation of their fundamental truths. "Language is our unique relationship to the Creator, our attitudes beliefs, values, and fundamental notions of what is truth. Our languages are the cornerstone of who we are as a People. Without our languages we cannot survive" (Assembly of First Nation 1990, p. 39).

Language, apart from being a medium of communication, also embodies the unique cultural wisdom of a people. The loss of any language is therefore a loss of humanity. From the forgoing, we can see that it is paramount to ensure the continuity of a language through the process of intergenerational transfer. This is because cultural diversity is essential to human heritage (UNESCO, 2003). There has been increased concern in the study of endangered languages by very many scholars with much emphasis in both Asian and African continents. UNESCO as an apex educational body has since structured policies to encourage the use of languages in several domains most especially in education. Several organizations such as Hans RausingEndangeredLanguages Project and DOBES Volkswagen foundation have risen up to support the documentation of some endangered languages through research. In most cases, languages that have been given much attention are languages with few speakers, whereas languages with a good number of speakers are being given a 'clean health bill' as not endangered. However this is not the case in reality, as a language like Igbo with over 18 million speakers is gradually losing some of its linguistic vitality.

Igbo is one of the three biggest indigenous languages, spoken in Nigeria with Hausa and Yoruba. The Igbo language has various dialects one of which is Ogwashi dialect. The Ogwashi dialect is spoken in Aniocha South Local Government Area of Delta state. Like in every other Igbo community, they possess a lot of folklore traditions, ranging 
from folk tales, riddles, legends, proverbs, idioms and myths. This predisposes them to use the Igbo language in a very rich and veritable manner. However, a close observation of the recent trend, in the passing down of the language from the previous generation to future generation has a lot of worrisome indicators of language endangerment. In September 2011, the Nigerian Vanguard published an article titled 'save Igbo language from extinction'. It observed the downward trend in the use of the Igbo language. Till date, it is a common practice to slam school children with all manner of punishment for speaking Igbo in schools. With this development, the speaking and writing of Igbo language started a slow but steady decline. Apart from the school environment, the language equally suffered serious bashing in other sectors of the Igbo nation. Back in individual Igbo homes, parents no longer told the scintillating, entertaining and educative folktales to their children. Several families no longer find it fashionable to talk to their children in Igbo language or teach them Igbo idioms and proverbs. Again in March 2014, another interesting news article caught my attention. It was published by Sunday Trust and was titled 'Amadioha lost his tongue'. For the sake of emphasis and also for the crucial nature of that article to this particular research work, I will present a true life story as narrated in the article.

My father often tells me stories about Kaka, his great grandfather and his prodigious ability to speak for minutes in nothing but proverbs. He tells me there was no day he was with Kaka that he did not learn a new proverb and gain a new profound insight about life. When it was time for Kaka to name my father, it was yet another proverb," Otuanyifurundu" which means: the way you see life. How this is a name is completely beyond me, but it speaks magnitude about Kaka's value systems, and the values of the culture in which he was embedded. The true Igbo culture is that of thought and sober reflection. Kaka was a man of a thorough understanding of himself and never took life at face value. He sought to share the knowledge he possessed especially with younger generations. He was a man of tales, proverbs and parables; because these are the words that add value to the language we speak. The Igbo pride is not merely in her art, and her prowess in natural and human resources, but also in her philosophy. Kaka's tongue was Igbo, his mind was Igbo, and most importantly, his thought was Igbo. Sadly though, my parents' generation in my opinion saw a pivotal change in the use of the Igbo language. They relegated the Igbo language to the language used in speaking to their kin. Even at home, English was used as a means of communication. My own little knowledge of Igbo is so shallow that I can barely hold a conversation without code-mixing. Always, I wish I had learnt to speak Igbo like Kaka. I wish Kaka had passed down all that knowledge to me and not gone with it to his grave (Sunday Trust 2014, p. 37).

From the foregoing, we are vividly exposed to how this process of the loss of aspects of a language can lead to language endangerment and finally language death. First it starts with the loss of an important feature of that language (such as proverbs in this case). With this slow but steady loss of such features, our people subject themselves to losing a mass of cultural wealth and the ancestral knowledge embedded in it; and this might in years to come translate into a total loss of the language itself. This research therefore takes a look at the intergenerational decline in the knowledge and use of proverbs in Ogwashi dialect with a view to draw the attention of its users to the on-going trend and its resultant effect of losing such aspect of the language.

\section{Literature review}

UNESCO (2003) asserts that a language is endangered when it is on the path towards extinction. A language is in danger when its speakers cease to use it in an increasingly reduced number of communicative domains, and cease to pass it on from one generation to the next. That is, there are no new speakers, either adults or children. This is to say that an endangered language is one that is at a risk of falling out of use. If a language loses all its native speakers, it becomes a dead language. Krauss (2007) says that a language is endangered if there is no transmission of it to young generation. Krauss projects that if children won't speak in a language in 100 years, then such a language is endangered.

On the causes of language endangerment, UNESCO (2003) posits that it may be the result of external forces such as military, economic, religious, cultural or educational subjugation, or it may be caused by internal forces, such as a community's negative attitude towards its own language. Internal pressures often have their source in external ones, and both halt the intergenerational transmission of linguistic and cultural traditions. Further, they explain that many indigenous people, associating their disadvantaged social position with their culture come to believe that their languages are not worth retaining. Mostly in this kind of situations, "people abandon their languages and culture with the hope of overcoming discrimination, to secure a livelihood, and enhance social mobility" (Batibo 2005, p. 25). On the world stage, Grenoble and Whaley (1998) estimate that 3,000 of the existing 6,000 languages will perish in the 
coming century; another 2,400 will come to near extinction leaving only 600 languages in the safe category. A criterion upon which a certain language's level of endangerment is measured is suggested by Batibo (2005); languages described as highly endangered are those which are currently deemed to be most vulnerable on the basis of the following indicators:

- The number of speakers currently using the language. A language with speakers fewer than 5000 is deemed highly endangered.

- The degree of bilingualism dominant in the language. Usually, any minority language whose speakers are highly bilingual in a dominant language is classified as endangered and its speakers are likely to shift to the dominant language.

- Socio-economic disadvantage of the minority language is a factor that endangers the concerned language.

- The prevalence of negative attitudes towards the minority language. Here, the speakers see no value in their language thus shifting to the dominant language which the speakers are positively inclined.

Irrespective of the benchmark number given by UNESCO for categorizing a language as safe, observation has shown that reliance on number of speakers as the standard for categorizing a language as safe or endangered is not always a correct yardstick. Going by this perspective, Bamgbose (1993) observes that the 'language loyalty criterion' is an important concept for defining endangerment. "Where loyalty is not strong, it is a short step to language shift and eventual language death" (Bamgbose 1993, p. 20). Further, he explains that there are languages spoken by thousands of speakers which are nevertheless endangered, while some languages with fewer speakers manage to resist the threat of endangerment because of strong language loyalty. Language endangerment is not automatic; it is slow but dangerous to the survival of any language. A common trend has been observed to take place especially among African languages. It starts with the gradual loss of features of a particular language. For a clearer picture on this phenomenon it is pertinent to cite practical examples at this juncture. In 2012, the Linguistics Association of Nigeria (LAN) held their $23^{\text {rd }}$ annual conference at university of Port Harcourt. The theme of the conference was on the numeral systems of Nigerian languages. One reoccurring observation from researches on various languages was the endangerment of numeral. For the sake of emphasis, let me present extracts from two of the works presented during the conference. In Oko language, the research highlights that "the main objective of this study is to contribute to the documentation of this most vulnerable aspect of the language by providing a detailed description of the Oko numeral system"(Atoyebi 2013, p. 43). In another paper, the researchers revealed that "preliminary investigation has shown that the numeral system of Fulfulde is severely endangered as children within the age bracket of 5-7 years can only count from 1-10, whereas those that fall within the range of 7-12 years could only count up to 20"(Abubakar and Abubakar 2013, p. 51).

In the African culture, proverbs are one of the most important features of a language. In the words of Chinua Achebe, "Among the Igbo, the art of conversation is regarded very highly, and proverbs are the palm-oil with which words are eaten" (Achebe 1958). Proverbs are meant to be considered and studied, not quickly digested and forgotten. The metaphor suggests that words are prepared by proverbs for digestion. Therefore, proverbs are the basis by which words/conversations are made. As it is in Igbo language, nuggets of popular wisdom abound in many African languages to accentuate and highlight discourses at given contexts. These expressions of wisdom are usually referred to as proverbs. In Africa, especially in the Nigerian context, expressions are not considered rich and intelligent except when they are duly laced with proverbs, which are many in our diversified cultures. "This informs why a traditional African would constantly punctuate his speech with appropriate proverbs and aphorisms to drive his point home" (Lawal 1992, p. 42). The ability to sum up ideas and experiences in captivating and succinct expressions has always been considered a sign of native intelligence, linguistic competence and cultural erudition. Such "wise sayings" are usually acquired and learnt from listening to the elders' talk. Given the vintage position that the elders occupy in various African traditions as the human repository of communal or primordial wisdom, they are the masters of eloquence, rhetoric and meaning.

The Igbos of Nigeria possess a rich folklore tradition; "among the various forms of folklore practiced by the people are folktales, riddles, legends, proverbs, idiom, myths and rituals" (Okolo 1985, p. 33). However, in the recent generation of speakers, observations show that the use of proverbs, other folklores and songs are dwindling in our day-to-day usage, in the process of communication. This is in line with Agbedo (2007, p. 56) assertion that one of the key indicators of language endangerment is the loss of oral tradition. This loss in most cases results from the process of intergenerational transfer. Ifode (2001) notes that a language only exists through the intermediary of the human beings who use it. The life span of human beings is in itself limited. Every generation has to learn the 
language afresh from a preceding generation of speakers if continuity is to be maintained. It is through this process of transfer from one generation to another that some features of the language disappear. These disappearances of aspects of a language invariably cause the language to lose its vitality. If such trends are not checked, we then have a decline in the transfer of linguistics knowledge from one generation of speakers to another which might eventually lead to endangerment. Agwuele (2010) observes that nowadays, it is common to hear sociolinguists say, loud and clear, that certain languages are threatened or endangered. Languages in this category are those that are in the process of being eclipsed in their cultural domain by other languages. The reversal of this threat or danger of death of a language is what is referred to as language saving.

Having observed this growing trend of loss in language, one obvious question then comes to mind. How healthy are these so called safe languages? In actual sense, if this trend is not stopped, these safe languages will keep on losing their vitality until they are no more. This is comparable to a situation where one is sick and as such his or her health keeps deteriorating, if nothing is done to improve the state of health, then the health deterioration might lead to eventual death.

\section{Choice of theoretical framework}

Language endangerment and vitality framework (LVE) is "[an alternative framework, a departure from Fishman's 8-level Graded Intergenerational Disruption Scale (GIDS) for assessing the status and vitality of languages in danger was proposed by a UNESCO panel of experts in 2003]" (Brenzingeret al. 2003, p. 8). The UNESCO framework establishes six categories in a scale of language vitality. These six major evaluative factors of language vitality are presented below

Factor 1: Intergenerational Language Transmission

The most commonly used factor in evaluating the vitality of a language is whether or not it is being transmitted from one generation to the next (Fishman 1991). Endangerment can be ranked on a continuum from stability to extinction. Even a rating of 'safe' (below), however, does not guarantee language vitality, because at any time, speakers may cease to pass on their language to the next generation. Six degrees of endangerment may be distinguished with regard to Intergenerational Language Transmission:

\begin{tabular}{lll}
\hline Degree ofEndangerment & Grade & Speaker Population \\
\hline Safe & 5 & $\begin{array}{l}\text { The language is used by all ages, from } \\
\text { children up. }\end{array}$ \\
Unsafe & 4 & $\begin{array}{l}\text { The language is used by some children in } \\
\text { all domains; it is used by all children in } \\
\text { limited domains. }\end{array}$ \\
Definitively & 3 & $\begin{array}{l}\text { The language is used mostly by the } \\
\text { parental generation and up. } \\
\text { severely endangered }\end{array}$ \\
critically endangered & 1 & $\begin{array}{l}\text { The language is used mostly by the } \\
\text { grandparental generation and up. } \\
\text { The language is used by very few } \\
\text { speakers, mostly of great-grandparental } \\
\text { generation. } \\
\text { There are no speakers. }\end{array}$ \\
Extinct & &
\end{tabular}

Factor 2. Absolute Number of Speakers

It is impossible to establish a hard and fast rule for interpreting absolute number, but a small speech community is always at risk. A small population is much more vulnerable to decimation (e.g. by disease, warfare or natural disaster) than a larger one. A small language group may also merge with a neighbouring group, losing its own language and culture. 
Factor 3: Proportion of Speakers within the Total Population

The number of speakers in relation to the total population of a group is a significant indicator of language vitality, where 'group' may refer to the ethnic, religious, regional or national group with which the speaker community identifies.

Factor 4: Shifts in Domains of Language Use

Where, with whom, and the range of topics for which a language is used directly affects whether or not it will be transmitted to the next generation. They outlined the following yardstick, grading from 0-5. Universal use (the language is used in all domains and for all functions). Multilingual parity (two or more languages may be used in most social domains and for most functions). Dwindling domains (the language is used in home domains and for many functions, but the dominant language begins to penetrate even home domains). Limited or formal domains (the language is used in limited social domains and for several functions). Highly limited domains (the language is used only in a very restricted number of domains and for very few functions). Extinct (the language is not used in any domain for any function).

Factor 5: Response to New Domains and Media

New areas for language use may emerge as community living conditions change. While some language communities do succeed in expanding their own language into new domains, most do not. Schools, new work environments and new media, including broadcast media and the Internet, usually serve only to expand the scope and power of a dominant language at the expense of endangered languages. Although no existing domains of the endangered language may be lost, the use of the dominant language in new domains may have mesmerizing power, as with television. If the communities do not meet the challenges of modernity with their language, it becomes increasingly irrelevant and stigmatized.

Factor 6: Availability of Materials for Language Education and Literacy

Education inthe language is essential for language vitality. There are language communities that maintain strong oral traditions, and some do not wish their language to be written. In other communities, literacy in their language is a source of pride. In general, however, literacy is directly linked with social and economic development. Books and materials on all topics for various ages and language abilities are needed.

Since its publication in 2003, LVE has been described, commented on and applied by various scholars; ElKirat (Beni Iznassen Amazigh in Morroco 2003), Legère(UNESCO, 2003 Vidunda language). Austin (2008: 217) describes LVE and singles out Factor1 (intergenerational transmission) as the most critical factor in language vitality: for a language to remain healthy, it must be spoken by the younger generation. As a result of her observation, we have taken time to elaborate on Factor 1 and Factor 2 (due to its needfulness in this study). It should however be noted that this is the first time LVE will be used to ascertain the level of vitality of a particular aspect of a language rather than the whole language in general. As we have already established that it is possible for languages which are perceived as 'healthy' to be endangered in real essence due to the gradual loss of some of its features (like in the case of numerals), we have thus elaborated this theoretical framework to accommodate this research work.

\section{Methodology}

This research is based on the Ogwashi dialect of Igbo spoken in Ogwashi-uku. Ogwashi-uku is made up of nine (9) clans known as ebo. The clans are; Umedei, Agidiahe, Agidiase, Azungwu, Ogbeubu, Ogbeumuokwuni, Okikakwu, Umuokwe, Ikelike. For the purpose of gathering accurate data for this research work, the direct observation method was adopted. In Ogwashi-uku, it is mandatory that at the end of the year (December), every clan holds a general meeting; one for the youths and one for the elders. It was during such occasion that the data for this work was gathered. First we constituted a research group of eighteen persons who attended all the meetings with the permission of the conveners. With the aid of a digital recorder (Olympus VN-712PC), all the proceedings of the meetings were recorded. The basic reason why this method was adopted is because often times when other methods like questionnaires are adopted, people do not really want to be honest enough to say that they do not know, so they tend to answer falsely and this adversely affects the data gathered.

All the data were collated and played and with the help of an elderly native speaker, we were able to identify all the proverbs used and their meanings. With the aid of a chart, we were able to represent all the information gathered from the eighteen different meetings. 


\section{Data Presentation and Discussion}

\begin{tabular}{lllll}
\hline Clans & $\begin{array}{l}\text { Number of } \\
\text { proverbs used } \\
\text { by the elders }\end{array}$ & $\begin{array}{l}\text { Knowledge of } \\
\text { proverbs in \% }\end{array}$ & $\begin{array}{l}\text { Number of } \\
\text { proverbs used } \\
\text { by the youths }\end{array}$ & $\begin{array}{l}\text { Knowledge of } \\
\text { proverbs in \% }\end{array}$ \\
\hline Umudei & 44 & $88 \%$ & 7 & $14 \%$ \\
Agidiahe & 50 & $100 \%$ & 4 & $8 \%$ \\
Agidiase & 40 & $80 \%$ & 4 & $8 \%$ \\
Azungwu & 61 & $100 \%$ & 5 & $10 \%$ \\
Ogbeubu & 43 & $86 \%$ & 9 & $18 \%$ \\
Okikakwu & 45 & $90 \%$ & 3 & $6 \%$ \\
Ogbeuokwuni & 44 & $88 \%$ & 7 & $14 \%$ \\
Ikelike & 49 & $98 \%$ & 7 & $14 \%$ \\
Umuokwe & 49 & $98 \%$ & 5 & $10 \%$ \\
\hline
\end{tabular}

Note: for easy representation of this work on a chart, $2 \%$ is awarded to every single proverb used in the data. However for the sake of convenience of representation, any figure above 50 is approximated as $100 \%$. This result is represented in the chart below:

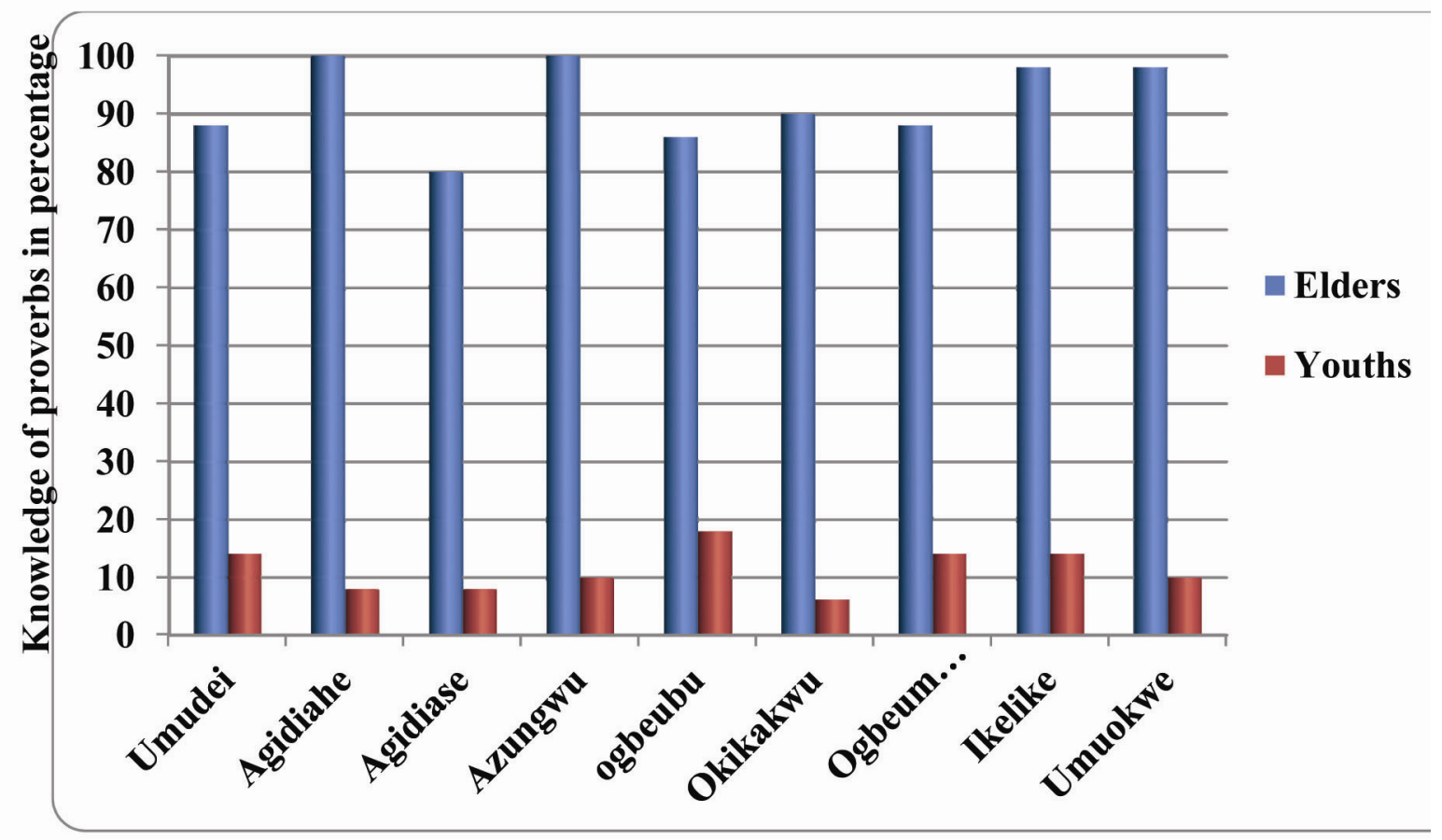

Clans

\subsection{Discussion}

From the data above, one can observe the wide gap between the elders and the youths of the various clans. For instance we can see from the data that while the elders scored from $80 \%-100 \%$ in the use of proverbs, the youths scored less than 20\%. This represents their knowledge and communicative ability in the use of proverbs in the language. In the analysis of the data gathered during the meeting, we made a lot of observation pointing to the decline in the knowledge of proverbs among the youths when compared to that of the earlier generation (the elders).

\subsubsection{Elders}

The meeting of the elders lasted for approximately 2-3 hours and so many proverbs were used. Ogwashi was spoken all through without any element of code-mixing or code switching. The usage of these proverbs was determined by the subject under discussion. For instance one of the agendas during the meeting was the issue of the increasing 
crime rate in the community, especially that of kidnapping. In addressing the issue, one of the elders, Chief Izu said: ókwúè bù ífé ànyí gè tínyé ónukwúé òfúmá, màkà nà ńdí bényí sì nà "àfúgó ékwùnè nè gbú ágádí mànà ékwúgé ánù nà nè gbú nwátá" (this issue is something we have to discuss critically because our people say that to see something going wrong and not speak up leads to the death of an elder, but when a warning is given and it is not adhered to leads to the death of children). He uses proverb to stress the need for the elders to seriously tackle this issue of kidnapping.

In addition to the observation above, where proverbs were used to stress the topic under discuss, we equally observed that it was possible for someone to speak for minutes by joining 2 or more proverbs. Example: òkúkú ní dí ànú ife, ikè ágúnkwó kà ónò à nuá, yá mè ńdí bényí jì sí nà izizí ní dí ànú ódụ nà èsó ini àná (a chick that does not heed to advice does so in the bosom of a hawk, that is why our people say that the fly that refuses advice follows the corpse to the grave). The above statements were made by one chief Iwedike. While commenting on the fact that youths of these days do not pay attention to advice.

Another distinct feature was the use of one proverb to negate another when driving home their points. For instance there was an issue raised before the house, about one of their daughters who got arrested because the boyfriend was caught with a gun. The elders then threw the case open for deliberations, whether to save the girl or not. At this point, Mr Elue remarks: ósisí wájì àkpá ézunà ésú tè wiàná mànà ńdí bényì sì nà mádù ádí ègbú ózú ọkwá (it is true that the stick used in dragging a millipede is thrown out with the millipede but our people also say that one does not kill someone who he will eventually end up burying). Also we noticed their ability to use another proverb to connect to an earlier statement made by another person as a way of supporting the idea. This was the case when Chief Okafor spoke in support of the point $\mathrm{Mr}$ Elue raised. In his remark, he ended by saying ífé Eluekwù dì míma,màkà nà ńdí bényí àsí nà kớfú ósè kơfụi mipkilité (I support what Mr Elue has just said because our people say that as it hurts the pepper, so it hurts the grinding stone). Proverbs were also used to make arguments. For example reacting to what $\mathrm{Mr}$ Elue and Chief Okafor said, Chief Onwuegbunem opposed the move to intervene immediately, until the girl learns her lessons, to buttress his point, he adds: òkwà ńdí bényì sì nà ágbíși gbá nwátà nà íkè, òmá nà íkè bù àhú? (Didn't our people say that when an ant stings a child in the buttocks, he realizes that the buttock is also part of the body?). Again we observe here that proverbs can be presented in form of a question.

\subsubsection{Youths}

In the youth section, they were a lot of deficiencies in the use of the language. Most youths could not use proverbs when contributing to the discourse. In some cases, we observed participants code-switching between English and Ogwashi. One important observation was that the few proverbs used, were simple ones, unlike the case of elders where it was possible to use more than one proverb. For instance, Iweanyi while commenting on the improvement in the number of turn out for the meeting commended them by saying: ànyí ánwàgá kà ànyísì kpókòmá òwé ànyímàkà nà ndí bényì sì nà ikèné ónyé nà niké ómè, úmé àdía mé òzó. (I commend all of us for gathering here today, because our people say that when you commend one for doing something good, it inspires him to do more).

Again from the records of all the proverbs used by the youths, we noticed a lot of repetition of proverbs. For instance among the Ogbeubu youths, ónyé áhụ jiádí àhụ́ áká (One does not roast his hands along with the yam he is roasting) was repeated four (4) times. While among the Ikelike youths, áká dókwámá óshá ómé únò (When someone take care of a bushy environment, it becomes homely). This has led us to assume that those who repeated proverbs either copied what others said or that these proverbs were the commonly used ones.

Also we observed that some youths do not really understand the meanings of these proverbs and as such, there were cases where some proverbs were used in the wrong context. For instance at the beginning of the meeting, the first speaker Mr Anonymous in commending the organizers for always making out time to hold the meeting annually said: ékènèm ứnụ shíné kà únú sì èmèmè ífe, mà kà nà ńdí bényí sì nà úchejikà ójì èlú àbùá (I thank the organizers for holding this event because our people say that it is providence that make a yam to produce two). This proverb is meaningless in the context in which he has used it. Evidence that showed the lack of shared semantic knowledge among this group is that when proverbs are used in some cases, the speakers tried to explain them, unlike the elders who easily related the meaning of proverbs to the point being raised. Again, we do not see that linguistic competence of using proverb synonymously, to continue from where a previous speaker stopped either to support or argue as was noticed in the case of the elders. This kind of communicative competence can only come from a strong understanding and mastery of the meanings of proverbs.

Finally, we also observed that in some other occasions, some youths were observed to have made proverbs half way; an indication that, they do not really know the proverb in full. Mr Anonymous, in an attempt to use the proverb: ofụ ǹchá lié sì nà òkpò nà tá áfọ́ (Someone who has seen little to eat, says what he has eaten causes him stomach upset) 
said: ơfụi nchá lié sì nà...únù màì kà wá sì èkwú eh (Someone who has seen little to eat then says... you people know how they say it).

\subsection{Application of LVE}

As already noted above, LVE, since its publication in 2003 has been used mostly by scholars to ascertain the vitality of a language as a whole. However in this work, we shall attempt to use this framework to ascertain the vitality in the use of an aspect of a language (proverb). This is so because it is possible for a language to face endangerment by gradually losing certain important communicative features due to lack of intergenerational transfer. In our application of LVE, two key factors are very important in this research.

\section{Factor 1: Intergenerational Language Transmission}

The intergenerational factor is perhaps one of the most important in the list as observed by Austin (2008). From the data gathered we have seen that proverbs are mostly used by generation of speakers between ages 45 and above. Going by the classification of intergenerational language transmission, this places the vitality of proverb usage between grade 3 (definitely endangered) and 2 (severely) endangered. This is because in the community, people who are referred to as elders are usually between the ages of 45 and above and are mostly married men. Thus we can then conclude that judging by the intergenerational factor; language feature (proverb) is used by parental generation and up.

\section{Factor 4: Shifts in Domains of Language Use}

Data gathered from oral interview suggest that in the time past, proverbs were used in all domains and for all function. The elders who were our respondents noted that during their days, proverbs were of common usage, at home, in church, place of work, in meetings etc. for various communicative purposes. This ties up with Achebe's remarks on the common use of proverbs in Igbo land. However, most regrettably though, this trend of communication has gradually ceased to exist in Ogwashi-uku. As noted by most of our respondents, the usage of proverbs is no longer common. In fact one of the elders noted that proverbs are now restricted to discussions within the elders usually during meetings like this. Thus we see a shift in domain in the use of proverbs; from language of universal use, to a language now used in highly limited domain.

\subsection{Reasons for the decline in intergenerational transfer and shift in domain}

One major reason for this decline in the usage of proverb is due to the lack of communicative function given to the Ogwashi language. Though most people have knowledge of the language, they prefer to communicate either in English or Nigerian Pidgin. Since practice makes perfect, due to the lack of usage of the Ogwashi language, the younger generation do not attain full competence like the previous generation of speakers. At home English or Nigerian Pidgin is mostly used and even in some cases where Ogwashi is spoken, proverbs are no longer used.

Again, another reason for this intergenerational gap is due to the loss of certain institutions in our modern societies. In the time past, when a child is 18years old, he is initiated into an age grade group. Groups such as this, play a very crucial role in educating younger generations on issues pertaining to the culture and values of the people through various means such as plays, story-telling, festivals etc. By so doing, such institutions help improve their competence in the language. However, modernization has eroded such important institutions and as such there is no longer room for interaction amongst individuals to exchange cultural knowledge.

Another factor is the issue of migration. People leave Ogwashi-uku to school in other areas or in search of greener pasture. At the point when most people leave the community, they do not necessarily possess a deep knowledge of the language as to enable them to communicate using proverbs. Some settle down in areas where they mostly use English or pidgin as a means of communication and only speak the language when they visit the village, which is in most cases occasional. In time, they begin to lose communicative ability in the language.

\section{Summary of findings, conclusion and recommendations}

Proverbs in Ogwashi perform varieties of function in day to day communication. As such, to communicate meanings effectively, one has to have a deep knowledge of proverbs in the language and how they are used. Without the knowledge and use of this proverb in the process of communication, the language becomes 'empty' and meanings are not fully realized. From the available literatures reviewed, we have been able to establish that proverbs are important aspect of language and culture. We also established that it is possible for a language to be ordinarily certified safe, whereas in real essence; it is gradually losing some of its feature and as such losing some of it communicative functions in certain domain where they are used. A clear instance is the case of numeral endangerment in some Nigerian languages. When people can no longer count in their native language, though they 
speak the language, you find them code-switching or in most cases communicate in English/Pidgin when the need of this numeral arises (for example, in the marketplace). In this paper, we looked at proverb as another aspect of this language that is rapidly heading towards extinction. From the research work, we made the following findings:

There is a rapid decline in the use of proverbs by younger generation in Ogwashi-uku and as such, such aspect of the language is gradually going into extinction. Findings show a shift in the domain of usage of proverb in Ogwashi; from an everyday means of communication to a more restricted usage in formal gatherings by the older generation of speakers. This shift in usage has adversely truncated the transmission of this vital aspect of the language to the younger generation.

We shall conclude this work by making this analogy on our own paradigm of the process of language loss. A language is like a chicken covered with feathers. The various features of a language (the idioms, numerals, proverbs etc.) are likened to the feathers of the chicken. Now when a chicken starts losing its feathers gradually and nothing is done about it, it gets to a point where it losses all its feathers and eventually dies. So it is for a language. Aside the words that make up a language, there are features of a language that give weight to the language; features like proverbs. So when these features are not being transmitted to the next generation, it gradually fizzles away. Numerals have fizzled out, and proverbs are gradually moving towards that trend. Invariably, the more this happens the closer the language draws to the danger of going extinct.

Finally, we recommend that asides documenting these languages, the attention of the local communities should be drawn to this trend and the need to preserve their language. This includes teaching children aspects like proverbs which are very important rudiments of the language. There is a saying in Ogwashi that: ónyé wá tàli ínú bá kọ́wálayá, égó wá jì nú nné nà níwì. The interpretation is that 'whoever you tell a proverb and explains it to him/her, the money used in marrying the mother is a waste'. This shows how important the knowledge of proverb is in the culture.

\section{References}

Abubakar, Muhammad / Abubakar, Akali. (2013). "The Fulfulde numeral system”. In: Ndimele, Ozo-mekuri / Chan, Eugene. (eds.): The numeral systems of Nigerian languages.(LAN Occasional Publication 2). M / J Grand Orbit Communications Ltd. / Emhai Press: Port Harcourt.

Achebe, Chinua. (1958).Things fall apart. Heinemann: Reading 1958.

Agbedo, Uchenna. (2007).Problems of multilingual nations: the Nigerian perspective. Fidgina Global Books: Enugu 2007.

Agwuele, Onyemachi. (2010).Globalization, dying languages and the futility of saving them, retrieved 01.03.2013, fromhttp://www.inst.at/trans/17Nr/1-3/1-3_agwuele17.htm 2010.

Assembly of First Nations. (1990).Towards linguistic justice for first nations. AFN Education Secretariat: Ottawa 1990.

Atoyebi, Joseph. (2013). "Oko numerals and their derivation". In: Ndimele, Ozo-mekuri / Chan, Eugene. (eds.): The numeral systems of Nigerian languages.(LAN Occasional Publication 2). M / J Grand Orbit Communications Ltd.Emhai Press: Port Harcourt 2013, pp. 41-50.

Austin, Peter. (2008).One thousand languages: living, endangered and lost. California University Press: Carlifonia 2008.

Bamgbose, Ayo. (1993). "Deprived, endangered, and dying languages". Diogenes 161 (41), 1993, pp. 19-25.http://dx.doi.org/10.1177/039219219304116102

Batibo, Herman. (2005).Language decline and language death in Africa: causes, consequences and challenges. Multi Lingual Matters Ltd: New York 2005.

Brenzinger, Matthias et al. (2003). Language vitality and endangerment, retrieved 17.02.2014, from http://www.unesco.org/culture/en/endangeredlanguages 2003.

Chukwuebuka, Ike. (2014). “Amadioha lost his tongue”. Sunday Trust 02.03.2014, p. 37.

Crystal, David. (2000).Language death. Cambridge University Press: Cambridge 2000.http://dx.doi.org/10.1017/CBO9781139106856

Dalby, Andrew. (2002).Language in danger. Penguin: London 2002. 
El Kirat, El Alame. (2003).Language endangerment in Morroco: the case of the BenilznassenAmazigh. Paper presented at UNESCO expert meeting on endangered languages 2003.

Fishman, Joshua. (2001).Can threatened languages be saved? Reversing language shift, revisited: A 21st century perspective. Multilingual Matters Ltd: Clevedon 2001.

Fishman, Joshua. (1991).Reversing language shift: theoretical and empirical foundations of assistance to threatened languages. Multilingual Matters: Clevedon 1991.

Grenoble, Lenore / Whaley, Lindsay. (1998).Endangered languages: language loss and community response. Cambridge University Press: Cambridge 1998.http://dx.doi.org/10.1017/CBO9781139166959

Hale, Ken. (1992). "On Endangered Languages and the Safeguarding of Diversity”. Language 68 (1), 1992, pp. 1-3.

Ifode, Shirley. (2001).An introduction to language in history and society. National Institute for Nigerian Languages Books: Aba 2001.

Krauss, Michael. (992). "The world's languages in crisis". Language, 1992, 68(1), 4-10. http://dx.doi.org/10.1353/lan.1992.0075

Krauss, Michael. (2007). Mass language extinction and documentation: The race against time. In: Miyaoka, Osahito et al. The vanishing languages of the Pacific rim. Oxford University Press: Oxford 2007, pp. 3-24.

Legère, Karsten. (2007). "Vidunda (G38) as an endangered language?" In: Doris Payne / Peña Jaime (e.ds.): Selected Proceedings of the $37^{\text {th }}$ Annual Conference on African Linguistics.Cascadilla Proceedings Project: Somerville, MA. 2007, pp. 43-55.

Nkwopara, Chidi. (2011). "Save Igbo language from extinction”. The Nigerian Vanguard 23.09.2011, p. 28.

Okolo, Betrand. (1985). "An analysis of Igbo proverbs and idioms". In: Lungstrum, Richard / Folarin, Antonia (e.ds.): Kansas working papers in linguistics 10 (1) 1985, pp. 33-55.http://dx.doi.org/10.17161/kwpl.1808.496

Sapir, Eward. (1929). "The status of linguistics as a science". Language 5 (8), 1929, pp. 207-214.http://dx.doi.org/10.2307/409588

Thanasoulas, Dimitrios. (2014). Radical pedagogy: the importance of teaching culture in the foreign language classroom, retrieved 17.02.2014, fromhttp://radicalpedagogy.icaap.org/content/issue3_3/7-thanasoulas.html 2001.

UNESCO. (2014). Language vitality and endangerment, retrieved 27.02.2014, from http://portal.unesco.org/culture/en/ev.php-URL 2003.

UNESCO. (2014).UNESCO red book of endangered languages retrieved 27.02.2014, from http://www.tooyoo.1.utokyo.ac.jp/Redbook/index.html 2003.

Wardhaugh, Ronald. (2002).An introduction to sociolinguistics (Fourth Ed.). Blackwell Publishers: Oxford 2002.

Woodbury, Anthony. (2014). What is an endangered language?, retrieved 17.02.2014, from http://linguisticsociety.org/files/Endangered_languages.pdf 2003. 


\section{Appendix}

\begin{tabular}{|c|c|}
\hline Proverbs & Interpretation \\
\hline ósọká ọnya & Too many cooks spoil the food \\
\hline úchejí ká ójì èlú àbùá & $\begin{array}{l}\text { It is providence that makes a yam to produce more than } \\
\text { one tuber }\end{array}$ \\
\hline ónyé áfụná ká ómè òmẹ kà ófù & Life is endurance \\
\hline kà ọnú n’gwúsu hà kà ómù ámú & You cannot give what you do not have \\
\hline ífé ónyé nwè kà ógbù ímí & You chastise what you have \\
\hline mádụ ádíabụ mádụ ògbọ́ ní hú mọ nádíá & One cannot dictate for a heir \\
\hline $\begin{array}{l}\text { àfứgọ ékwùnè nè gbú ágádimanà èkwúgé ánù nà è gbú } \\
\text { nwátà }\end{array}$ & $\begin{array}{l}\text { When something goes wrong and nothing is being said, } \\
\text { the elders take the blame, but when something is said but } \\
\text { not adhered to then the youth/ children take blame what } \\
\text { an elder sees when sitting, a child can never see when } \\
\text { standing. }\end{array}$ \\
\hline ágádi né kwú ónú é shíe yàtà, ógá bù, òbùá kọ kọ lọ kọ & $\begin{array}{l}\text { When an elder complains, she/he is seen as a noise } \\
\text { maker, but what he/she says becomes very evident later } \\
\text { on }\end{array}$ \\
\hline ògbú mpé jinà yọ sí ònwé àyọ̀ & $\begin{array}{l}\text { A farmer who plants the root of a yam instead of the } \\
\text { tuber is only deceiving himself }\end{array}$ \\
\hline ízízí ní dí ànú ọdụ nà èsó ínì àná & $\begin{array}{l}\text { The fly the refuses advice follows the corpse to the } \\
\text { grave }\end{array}$ \\
\hline úchè ónyé álabù ózílíé & the senses of a madman is his direction \\
\hline ọfụ n’há líé sì nà òkpò nà tá áfọ & $\begin{array}{l}\text { Someone who has seen little to eat then says what he has } \\
\text { eaten causes him stomach ache }\end{array}$ \\
\hline ìkpá lò sié ìlòlò ọtọ á ná áfọ́ & $\begin{array}{l}\text { whatever thought a poor man conceives ends up in his } \\
\text { stomach }\end{array}$ \\
\hline kọfụ ósè kọfụ mpkílíté & $\begin{array}{l}\text { The same thing that affects the grinding stone also } \\
\text { affects the grinder }\end{array}$ \\
\hline ńkílí ńkílí kà wá nèkílí ódòdó & A red cloth always attract attention \\
\hline ọkúkù ní dí ànú ífé, íké ágúnkwokà ọnọ à núa & $\begin{array}{l}\text { A chick that does not heed to advice does so in the } \\
\text { bosom of a hawk }\end{array}$ \\
\hline ósísí wájì àkpá ézunà ésú wị à ná & $\begin{array}{l}\text { The stick used in dragging a millipede is thrown out } \\
\text { with the millipede }\end{array}$ \\
\hline ọkụkụ ámáná égó ọkà & A fowl does not know the value of corn \\
\hline ọkụkù ná bọ íkéíké, ànì kà ósì èbídó & $\begin{array}{l}\text { A chicken that scatters the earth with much vigour } \\
\text { started as a chick }\end{array}$ \\
\hline àgbíṣi gbá nwátà nà íkè, ọmá nà íkè bụ àhụ́ & $\begin{array}{l}\text { When an ant stings a child in the buttocks, he realizes } \\
\text { that the buttocks is also part of the body }\end{array}$ \\
\hline ónyé áhư jí ádị àhụ áká & $\begin{array}{l}\text { One does not roast his hands along with the yam he is } \\
\text { roasting }\end{array}$ \\
\hline áká dókwámá ọshaòmẹ ụnọ & $\begin{array}{l}\text { When someone takes care of a bushy environment, it } \\
\text { becomes homely }\end{array}$ \\
\hline nwátà pánịe ńnaàkpà ámụ áyọchíé ányá & $\begin{array}{l}\text { When a child raises his father up, he is blinded by his } \\
\text { father's manhood }\end{array}$ \\
\hline
\end{tabular}




\begin{tabular}{|c|c|}
\hline mádụ ámá nọ nímé mílí ńchà ábanányá & $\begin{array}{l}\text { One cannot be in the middle of a river and get blinded } \\
\text { by soap }\end{array}$ \\
\hline ékwénné ńné zuáḍi ékwé dí ànụ́ & $\begin{array}{l}\text { A girl who could not be well brought up by the mother } \\
\text { cannot be married to a man }\end{array}$ \\
\hline òkpòhó té ájọ ófé, ọláchá gbụẹé ónwé & $\begin{array}{l}\text { When a woman prepares a bad soup, she ends up licking } \\
\text { it alone }\end{array}$ \\
\hline úkwú òkúkù zò nwá á dí ègbúé & $\begin{array}{l}\text { When a mother hen steps on its chick intentionally, it } \\
\text { doesn't kill it }\end{array}$ \\
\hline áshịi ọkpà ábụ́ná áshịi ńnékwú & The tail of a cock is not the tail of a hen \\
\hline jí wá sùnyè nwátà náká ádí áhùá ọ́kú & $\begin{array}{l}\text { A piece of yam given to a child by his mother is never } \\
\text { too hot for him }\end{array}$ \\
\hline úchè kà wá jì à láchá ófé dì ọkụ̀ & Wisdom is applied when licking hot soup \\
\hline úchè kà wá jì ègbú òdùdù bèlì nà ńjọ nà àkpàmù & $\begin{array}{l}\text { To kill a fly that has perched on the scrota sack, one } \\
\text { requires wisdom }\end{array}$ \\
\hline mádù ádí égbú ózú ọ́kwa & $\begin{array}{l}\text { One does not kill someone who he will eventually end } \\
\text { up burying }\end{array}$ \\
\hline $\begin{array}{l}\text { òfú ónyé síélí ìdúmù ńní, wè lí pùée. mànà ìdùmù siélí } \\
\text { òfú ónyé ńní ọgbùá }\end{array}$ & $\begin{array}{l}\text { When an individual cooks for a community, the } \\
\text { community will finish it up, but when an entire } \\
\text { community cooks for an individual, it becomes a } \\
\text { problem to him }\end{array}$ \\
\hline ífé ónyé gbànkítì kà íbẹ mènèsḥiẹ & When some stays idle, he is been overtaken by others \\
\hline ífélé ókeijì nyụ́ ńsị nà ụ́nọ ádí è̉kwẹ ètéshí gbó & $\begin{array}{l}\text { When a man defecates on his bed while sleeping, he } \\
\text { stays indoors because of shame }\end{array}$ \\
\hline mkpí nụchá șiá, òbiệlí mkpòdù & $\begin{array}{l}\text { No matter how stubborn a he-goat is, it still ends up as } \\
\text { meat }\end{array}$ \\
\hline áká ádí ánwụ́ ònyìnyò & One's hand cannot grip a shadow \\
\hline nwátà gbúé ókèì mmmà, ò láhụ́ ilo & $\begin{array}{l}\text { When a child attacks his elder with a machete he ends up } \\
\text { homeless }\end{array}$ \\
\hline
\end{tabular}

